\title{
A Semi Autonomous Model to Strengthen the Lowest Bureaucracy: A Case Study in Wonosobo Regency, Central Java, Indonesia
}

\author{
Simin* \\ Bambang Tri Harsanto \\ Slamet Rosyadi \\ Wahyuningrat \\ Department of Public Administration \\ Jenderal Soedirman University, Indonesia \\ ${ }^{*}$ Corresponding Author
}

Doi: $10.2478 / \mathrm{mjss}-2018-0060$

\section{Abstract}

Local government law changes in Indonesia have brought a significant change in terms of authority management in particular kelurahan government as the lowest bureaucracy. Previously, some Kelurahans have the authority to manage and develop funds to improve the community welfare. However, they just recently conduct the administrative functions to implement some duties from the upper government level. This change negatively influences the performance level of Kelurahans. Using some kelurahans in Wonosobo Regency Central Java with a qualitative method, this research tries to explore what consequences may occur as the result of local governance law changes. The results suggest that there should be various efforts to strengthen the institutional capacity of Kelurahans instead of letting them have poor performance. This research provides the theoretical and practical knowledge on the semi autonomous model of lowest bureaucracy for strengthening institutional capacity. Implication of findings from this research is the lowest governmental institution needs to be empowered with more authorities and development budgets in order to improve their actions for the community welfare.

Keywords: local institutional capacity, semi autonomous, authority management, kelurahan, Indonesia

\section{Introduction}

Public management plays an important role in driving the function of government's administration (Meier and O'Toole, 2002). With good public management, the resources that regional governments have can be effectively used to reach their goal of making their people prosperous. This way, people's satisfaction can be achieved through the improvement of regional governmental executing organization's management quality (Im and Lee, 2010).

Many efforts have been made to improve the regional government's management to make it better. One of them is by institutional strengthening in the effort of clearly distinguishing the function and authority of bureaucracy (Zaharia, 2011). The embodiment of these efforts can be seen from the existence of regulations related to authorization both administratively and politically, including the fulfillment of adequate budgets at each state administrator level.

As the people's demand for better service quality develops and grows more dynamically, regional governments need to prepare a more efficient regional agency organization. This character is shown by a slim institutional structure. The opposite, i.e. thick institutional structure, in addition to being inefficient, has the potential to have main task and function overlapping among the existing organizations. Also, the coordination will even be harder, thus there is a great chance for a conflict 
line between those organizations themselves to occur. On the contrary, a slim regional administrative organization will result in better service quality. Such a state of affairs leads to uncomplicated institutional structure and easy-to-understand service procedures for the people, and it also provides the people with legal clarity and certainty. A slim organization will producre a higher quality service and make things easier for the service users (Maarse and Janssen, 2012).

One of these efforts to streamline goverment's organizational structure can be seen from the change in kelurahan's position. The enforcement of Law No. 23 of 2014 on Local Government makes kelurahan lose its status as a local agency. Article 209 paragraph (2) states that Regency/Municipality's Local Agencies consist of: a) Local Secretariate, b) Regional House of Representatives (DPRD) Secretariate, c) Inspektorat, d) Offices, e) Bodies, and f) Districts (Kecamatan). It means kelurahan is no longer a local agency, because it is not mentioned in that article. This is different when compared to the provisions in two previous Local Government Laws which expressly mention kelurahan as a local agency. As a result, the delegation of authority both administratively and politically from regency/municipality to kelurahan has changed as well.

Prior to the issuance of Law No 23 of 2014, the issue about the position of a kelurahan has actually surfaced. In its relation to districts, the duties and responsibilities between kelurahans and districts are deemed to have something in common. The only difference lies in the degree of coverage or extent of their respective duties and responsibilities. This is because kelurahan frequently does not receive any transfer of authority from districts. Despite the regulation governing the authorities to be transferred to kelurahans, in its implementation this is not so optimal since kelurahans are not equipped with adequate human resources, facilities, infrastructures nor budget. It is often the case as well where the technical agency is reluctant to transfer the authority which as per regulation has been transferred to districts/kelurahans. At the end of the day, these problems have caused inefficiency in the use of government budget to finance the two agencies.

Kelurahan is a street-level bureaucrat in charge of providing services directly to the community. Therefore, kelurahan ought to have a clear and extensive authority in order to improve their performance, particularly in serving the community. Nevertheless, the existence of an organization, particularly kelurahan, has not yet been capable of playing its role to be the frontliner of service provision and to give as great usefulness as possible for people in their area. Local governments are deemed as fail to optimally assign a strategic role for kelurahans. This might be worsened by this change in kelurahan's position. Below is an illustration of difference in kelurahan's position before and after the enforcement of Law No. 23 of 2014 on Local Government.

The decreased authority owned by kelurahans inevitably has some effect on their authority to prepare their planning. The preparation of kelurahan's strategic plan will lose its function as a participatory planning document at kelurahan level. This is because the plan and strategy will be made at district level. Kelurahan is no longer free to prepare its own strategic planning. It is also certain that kelurahan will only be a participant in District Musrenbang (Development and Planning Forum). In the past, even when it served as an SKPD (Satuan Kerja Perangkat Daerah or Local Government Agency Unit), many participatory suggestions from the community were not accommodated. They were stuck at District level. It seems to be worse now that kelurahan does not stand alone as an SKPD. It will eventually lose its function as the channel for people to get their voices heard.

As its status is no longer a local government agency, this means the government (including regency/municipality) does not decentralize its authority anymore to kelurahan. The kelurahan's function as an agency with complete power to organize its people is no longer present. At this rate, local governments need to do something about it in order for the sustainable service provided to the community at kelurahan level. However, it is important to provide kelurahan with some greater space in making the efforts to lead their people to welfare improvement.

Many issues dealing with the position of kelurahan also occur in Wonosobo Regency. In this regency, proposals have been submitted by some kelurahans to change their status from kelurahan to village (Source: http://www.radarkedu.com/wonosobo/demo-warga-minta-desa-dikembalikan/). This is all driven by the increasingly higher demand from the society for better public service provision and regional development. In addition, the village fund factor currently distributed to villages has also been a specific attraction for kelurahan to change into village (Harsanto, 2017:196). 
The local government should immediately deal with the problematic situation occuring in kelurahans. It is important for Wonosobo Regency government to investigate the current kelurahan's institutional condition as well as its projection in the future. Therefore, a study on kelurahan should be intended to produce some policy alternatives or choices the Wonosobo Regency Government could take to improve kelurahan's institutional system. Additionally, this study also provides alternative choices of change from kelurahan into village along with the analysis of its impacts. Through such study of kelurahan, Wonosobo Regency government will discover the institutional capacity owned by kelurahan starting from the structural capacity or authority, human resources, budget and also performance of the kelurahan itself.

\section{Literature Review}

The main objective of decentralization is an answer to enter the new game era which brings along new rules in all aspects of human life in the future. In such an era, the government might find it hard or even lose the power to control many issues, but the government will be too small to solve all problems encountered by the society (Shah, 1997).

Other arguments regarding the importance of decentralization as follows: 1) the increasingly wider gap between central government and those in regions (Carreras, 2015); 2) the central leadership's frequent failure to understand the difficulties in regions; 3 ) the frequent technological slackness due to the frequent absence of alternatives available to local officials; 4) the communication gap which frequently causes the projects designed by the central government not matching with the government and people's needs and conditions in regions (Sutiyo and Maharjan, 2017).

In the context of development, the development decentralization at region level can expand the development benefits to lower level, particularly to improve the economic growth of the poor who lives mostly in areas far away from the central government (Johan van Zyil et al, 1995:6). Other researchers also find that decentralization can distribute economic results at local level and it is intended to improve the public service quality, accountability, responsiveness of local governments and local institutional capacity strengthening (see Nannyonjo \& Okot, 2013; Boasiako, 2010; Ribot, 2002).

Nevertheless, in order to improve the decentralization effectiveness it is important to adjust the institutions at local level. The environmental challenge encountered by local government demands an organizational strengthening to allow the local government to answer its people's needs and manage the change process itself. In this case, decentralization requires local government reorganizing or strengthening to enable a more efficient and effective management of the organization's resources (Fenwick and Bailey, 1998).

\section{Method}

This research was conducted in Wonosobo Regency, Central Java Province, Indonesia. It was conducted from April to October 2017. The data were primary and secondary ones. The primary ones were collected by in-depth interview with informants which consist of lurah (kelurahan chief), regency officials in charge of village governments, district chief, and the management of Kelurahan's Community Empowerment Institution or Lembaga Pemberdayan Masyarakat Kelurahan (LPMK) and public figures of kelurahans. In-depth interview was focused on such aspects as kelurahan's authorities, kelurahan's budget, kelurahan agency's resource capacity, and kelurahan's institutional strengthening model. The secondary data were collected from such documents entitled Kabupaten Dalam Angka, Kecamatan Dalam Angka and program reports from Kelurahan. In this research, the data were analyzed using the interactive model as suggested by Milles, Huberman and Saldana (2014:14). In this interactive model, there are three main cycles, namely data condensation, data display and conclusion drawing. To test the data validity, this research uses data source triangulation. In this case, the data collected through interview are compared among the informants and against the secondary data to improve the credibility and validity of data. 


\section{Result and Discussion}

\subsection{Kelurahan's Institutional Strengthening.}

From the analysis results, this study found that kelurahan's low performance in the field of development was due to the fact that kelurahan no longer has the authority to determine its revenue sources and asset management independently. Since they did not have such an authority, kelurahan had no power to procure their development funding. With the enforcement of this government regulation, kelurahan did not have the authority to manage their human resources needs independently.

In order for kelurahan to have the ability to implement development as the case with village, the commitment (political will) from the local government is required to make some kelurahan's institutional strengthening. The findings in the field in regard to this institutional strengthening can be detailed as follows:

\subsubsection{Strengthening the Authority of Kelurahan Institution}

Prior to the issuance of Government Regulation No. 18 of 2016 on Local Government Apparatus, kelurahan had the authority to manage its own revenue sources independently which can be used to manage the development in its region. Upon its issuance, that authority is revoked, rendering kelurahan weak in terms of their income. This results in kelurahan's low performance in many fields including: development, public service, governmental administration, community empowerment and kelurahan's income (see Table 1). For kelurahan to gain the adequate ability in development once again, it is important for the government to have political will to implement the following policies: (1) kelurahan is authorized to make regulations regarding the determination of revenue sources which can be managed by kelurahan, such as the establishment of field rent, building rent, kiosk rent and the establishment of levies of market, parking and public toilet, (2) kelurahan is authorized to manage assets as its revenue sources, such as the management of lands formerly known as Bondo desa (village's property). Being assigned this authority, it is expected that kelurahan can have its own revenue sources which can be used to fund the development in its region.

Table 1. Kelurahan's Performance Accomplishment in General

\begin{tabular}{|l|l|l|}
\hline No. & Performance Indicators & Program Accomplishment \\
\hline 1 & Budget absorption & $\begin{array}{l}\text { - The programs implemented had been as specified in DPA } \\
\text { - Program implementation accomplishment: } 100 \% \text { implemented } \\
\text { - Beyond DPA: PNPM } \rightarrow \text { P2KP programs } \\
\text { - In general, kelurahan's budget absorption has been } 100 \text { percent }\end{array}$ \\
\hline 2 & Public service & $\begin{array}{l}\text { In terms of public service, there is still a limitation in terms of procurement of kelurahan's } \\
\text { infrastructures and facilities }\end{array}$ \\
\hline 3 & $\begin{array}{l}\text { Governmental } \\
\text { administration }\end{array}$ & $\begin{array}{l}\text { - The estate tax income target has not been } 100 \text { percent accomplished } \\
\text { - Most kelurahans have not made organization's performance assessment } \\
\text { - They have not been 100 percent administratively well-performed. }\end{array}$ \\
\hline 4 & $\begin{array}{l}\text { Community } \\
\text { empowerment }\end{array}$ & $\begin{array}{l}\text { - The implementation of } \text { kelurahan planning and development forum has not been fully effective } \\
\text { - Most of them do not have Kelurahan-owned enterprises } \\
\text { - Human resources quality is low }\end{array}$ \\
\hline 5 & Kelurahan's income & - The income obtained through kelurahan's locally generated recurring revenues is less optimal \\
\hline
\end{tabular}

Source: Processed primary data, 2017

\subsubsection{Strengthening sources of kelurahan institution's income}

The enforcement of Government Regulation No. 18 of 2016 concerning Local Government Apparatus has stripped kelurahan off their revenue sources which can be managed independently. This is because kelurahan is now merely part of district's SKPD, rather than a separate SKPD. Any funding needed in development activity is highly dependant on the budget alloted at district level for each kelurahan in its working area. This makes kelurahan unable to manage development programs in its own area as needed by its people. 
For kelurahan to have adequate ability in performing some development in their region, there is a need to strengthen the management of kelurahan institution's revenue sources, such as (1) managing kelurahan's income deriving from rent, levy, urban taxes (estate tax, restaurant, food catering service provider, hotel), (2) establishment of Kelurahan-Owned Enterprises or Badan Usaha Milik Kelurahan (BUMKel) and (3) Regency Government's commitment to procure fund specifically located for kelurahan (ADK)

\subsubsection{Strengthening kelurahan's human resources (SDM)}

The consequence of making kelurahan institution part of district's SKPD is that kelurahan no longer has the authority to determine the personnel they require. All employment regulations should refer to the policies decided on by the district and Local Employment Agency at regency level. Meanwhile, kelurahan's function has something in common with that of village in providing services to the community. At village level, the service to the society can be provided by the agency optimally since all of their officers are living in the same village as the service users, allowing the services to be given to them optimally for 24 hours. Meanwhile, at kelurahan level not all of its officers live in the area where they are assigned, thus the services to the community can only be provided less optimally. Therefore, it is important for the local government to make policies which will enable kelurahan officers to stay in the kelurahan they are assigned by providing an official residence for kelurahan officers for them to stay hence the services can be optimally given by these officers to their community.

To deal with the personnel deficiency at kelurahan level, it is important for local governments to authorise kelurahan institution to recruit contract-based personnel to provide non-administrative service at kelurahan level. To be this contract-based personnel, those former village officers can be appointed. With their experience, it is expected that they will have possessed the skills required to perform the job at kelurahan level.

\subsection{Kelurahan's Institutional Capacity Strengthening Model}

Having identified the factors which cause the kelurahan institution's low performance and described those factors which can improve this performance, a kelurahan's institutional capacity strengthening model can be made. This model is expected to help kelurahan to have the ability in providing development service to the community better.

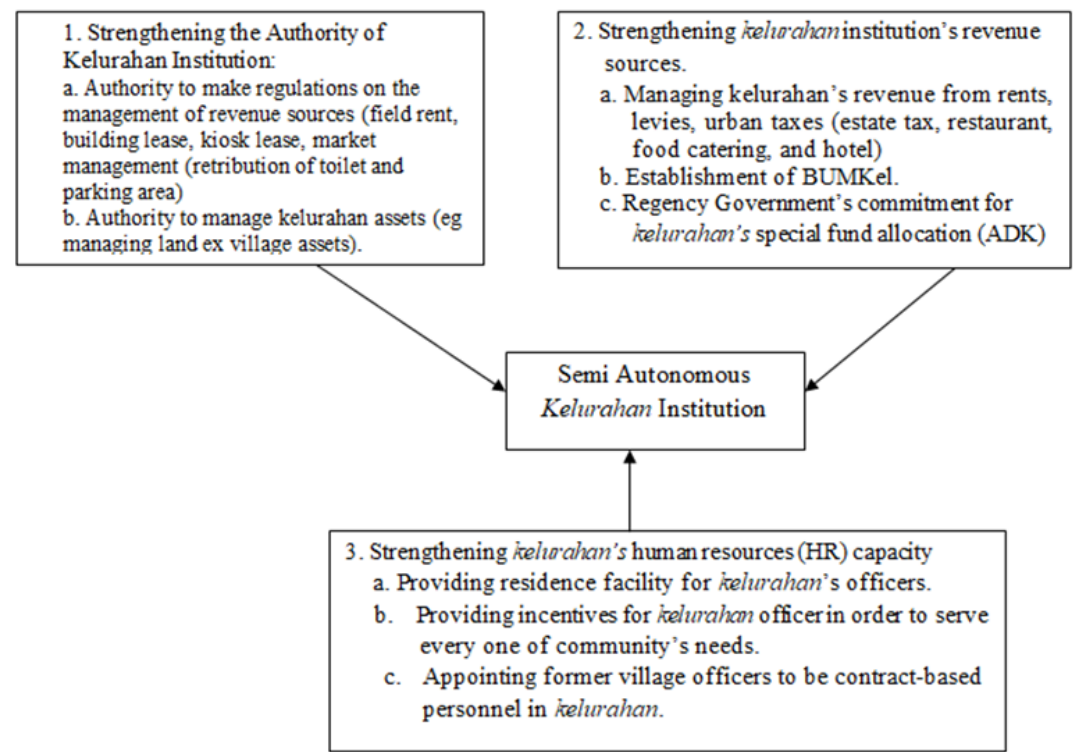

Figure 1. A Semi Autonomous Model to Strengthen Kelurahan's Institutional Capacity 
Based on the data analysis, this research formulates a Semi Autonomous Model to strengthen Kelurahan's institutional capacity. With the village fund being managed by village government, kelurahan government needs to be strengthened in terms of their authority, budget sources and human resources capacity. The semi autonomous model is chosen to distinguish it from the village government's autonomous model. Kelurahan institution is indeed different from that of Village. Several important aspects which distinguish the two can be seen from their officer's status where kelurahan's officers are civil servants (PNS) while village officers' status is non-Civil Servants. Another important distinction is that kelurahan is an administrative institution, while village is a governmental institution with political rights. Therefore, a semi autonomous model is not intended to create an understanding that kelurahan will be equated to village. Kelurahan remains a part of Regency's governmental organization, yet its functions are expanded to allow it to play more role for public interest at kelurahan level.

Kelurahan's decreased performance strongly indicates that a new model is required to strengthen kelurahan in the future. This strengthening is intended to enable kelurahan's capacity can keep on growing, be it its officers or its organization, to perform such functions as government's administration, public service and community empowerment. According to UNDP, the process of developing institutional capacity also has something to do with the efforts of improving ability to assess and react to future needs and keep on updating their relevance and improving effectiveness (Horton et al, 2003). When kelurahan is strengthened, it is expected that both the capacity of kelurahan officers and institution can adapt to changes.

\section{Conclusions}

From the research results above, the following conclusions can be drawn:

1. The determinant factors of the low performance of kelurahans in Wonosobo Regency are the low authority that kelurahan institution has, the minimum budget for kelurahan, and limited quantity and quality of human resources.

2. Kelurahan's institutional capacity strengthening efforts are focused on the following institutional aspects:

a. Strengthening Kelurahan Institution's Authority (Expanding the authorization to kelurahan with local government/regent regulations)

b. Strengthening kelurahan institution's revenue sources

c. Strengthening kelurahan's human resources (HR) capacity

d. The kelurahan institutional model which is currently administrative needs to be changed into semi autonomous one in order to adapt to social and economic changes in its environment.

\section{Implicaton}

For kelurahan institution to have the ability to provide development service to the community well, it is important for the local government together with local house of representatives to issue local regulations or at least for Regents to issue Regent regulation regarding Kelurahan capacity institutional strengthening to allow it to have the ability to provide development service to the society well. The local regulations or Regent regulations to be made ought to include the authority of kelurahan (1) in making rules on management of revenue resources and the in managing kelurahan's assets, (2) in managing kelurahan's revenues and establishing BUMKel and (3) in appointing its contract-based employees.

\section{Acknowledgement}

The researcher would like to thanks to the Institute for Research and Community Service (LPPM) of Jenderal Soedirman University that has facilitated multiyears research funding from 2016 to 2017. We also thanks to all parties especially Government Section of Wonosobo Regency which has facilitated data and research permit. 


\section{References}

Anonim. (2015). Demo, Warga Minta Desa Dikembalikan. Available at http://www.radarkedu.com/wonosobo/demo-warga-minta-desa-dikembalikan.

Boasiako, KBA. (2010). Public Administration: Local Government and Decentralization in Ghana. Journal of African Studies and Development 2 (7): 166-175.

Carreras, Y.I. (2016). Fiscal Decentralization and Inequality: The Case of Spain, Regional Studies. Regional Science, 3 (1): 295-302, doi: 10.1080/21681376.2016.1183513.

Fenwick, J \& Bailey, M. (1998). Decentralisation and Reorganisation in Local Government. Public Policy and Administration, 13 (2): 26-39.

Harsanto, BT., Rosyadi, S., Wahyuningrat, \& Simin. (2017). Strengthening Institution of 'Kelurahan' After Implementation of the Law of No. 23/2014 on Local Governance. Masyarakat, Kebudayaan dan Politik 30 (2): 188-196.

Horton, D., Alesaki, A., Bennett-Lartey, S., Brice, K.N., Campilan, D., Carden, F., Silva, J.S., Duaong, L.T., Khadar, I., Boza, A.M., Muniruzzaman, I.K., Perez, J., Chang, M.S., Vernooy, R., \& Watts, J. (2003). 'Evaluating Capacity Development: Experiences from Research and Development Organization around the World'. International Service for National Agricultural Research, Netherlands.

Im, T. \& Lee, S.J. (2010). Does Management Performance Impact Citizen Satisfaction. Conference Paper presented in KAPA Conference, Seoul South Korea.

Maarse N. \& Janssen, M. (2012). The Need to Adjust Lean to the Public Sector. In: Scholl H.J., Janssen M., Wimmer M.A., Moe C.E., Flak L.S. (eds) Electronic Government. EGOV 2012. Lecture Notes in Computer Science, vol 7443. Springer, Berlin, Heidelberg.

Meier, K. J. \& O'Toole, L. J. (2002). Public Management and Organizational Performance: The Effect of Managerial Quality. J. Pol. Anal. Manage., 21: 629-643. doi:10.1002/pam.10078.

Milles, B.M., Huberman, A.M., \& Saldana, J. (2014). Qualitative Data Analysis, A Methode Sourcebook, USA: Sage Publication. Inc.

Nannyonjo, J. \& Okot, N. (2013). Decentralization, Local Government Capacity and Efficiency of Health Service Delivery in Uganda. Journal of African Development 15 (1): 125-158.

Ribot, J. (2002). Democratic Decentralization of Natural Resources: Institutionalizing Popular Participation. World Resource Institute.

Shah, A. (1997). Balance, Accountability, and Responsivenes, Lesson about Decentralization. Policy Research Working Paper No. 2021, World Bank, Washington, DC.

Sutiyo \& Maharjan, KL. (2017). Decentralization and Rural Development in Indonesia. Availabele at http://www.springer.com/978-981-10-3207-3.

Van Zyil, J., Barbosa, T., Parker, AN. \& Sonn, L. (1995). Decentralized Rural Development and Enhanced Community Participation. Policy Research Working Paper No. 1498, World Bank, Washington, DC.

Zaharia, P. (2011). Autonomy and Decentralization - Current Priorities in the Local Public Administration Management. The Annals of the Stefan cel Mare, 11 (2) (14):288-292. 